\title{
Produção imobiliária de habitação em Curitiba na década de 2010: algumas reflexões
}

\author{
Residential real estate production in Curitiba \\ in the 2010s: some reflections
}

Fabiana Moro Martins [I] Gislene de Fátima Pereira [II]

\section{Resumo}

A produção do espaço visando à reprodução do capital intensificou no Brasil na última década, mediante a financeirização do setor imobiliário e a execução do Programa Minha Casa Minha Vida, que fomentou a produção de habitação para o segmento econômico pelo mercado. Considerando esse cenário, este texto apresenta os resultados da pesquisa sobre a produção de habitação multifamiliar em Curitiba entre 2010 e 2018. 0 estudo identificou os agentes e as características dos empreendimentos e seus efeitos no espaço urbano. Confirmou-se a expansão, numérica e territorial, da produção imobiliária de habitação, com forte participação das empresas de capital aberto e com diferentes estratégias de atuação conforme a conjuntura econômica. Essa produção reforçou a segmentação e a fragmentação do espaço na cidade.

Palavras-chave: produção do espaço; mercado imobiliário; habitação; financeirização; Curitiba.

\begin{abstract}
Space production as a means of capital reproduction was intensified in Brazil over the last decade, through the financialization of the real estate sector and the execution of the Minha Casa Minha Vida housing program, which encouraged the production of affordable housing by market agents. Considering this scenario, the text presents the results of a research on the multifamily housing developments concluded in the city of Curitiba between 2010 and 2018. The study identifies the agents and characteristics of the projects and their effects on urban space. The expansion of residential real estate production, both numerical and territorial, was confirmed, with a strong presence of publicly traded companies and the employment of different strategic actions according to the then-current economic scenario. This production has reinforced the segmentation and fragmentation of the city space.
\end{abstract}

Keywords: space production; real estate market; housing; financialization; Curitiba. 


\section{Introdução}

No início dos anos 2000, os mecanismos regulatórios e institucionais criados pelo Sistema de Financiamento Imobiliário (SFI) aumentaram as garantias para investimento privado em companhias do ramo de construção e incorporação no Brasil e estimularam a produção de habitação pelo mercado. Várias empresas do setor lançaram ações na Bolsa de Valores de São Paulo (Bovespa), e sua capitalização permitiu investir tanto em incorporação como na formação de bancos de terras. Além disso, a estabilidade econômica do período e a baixa taxa de desemprego no País fortaleceram a retomada do crédito habitacional. Mais adiante, o programa Minha Casa Minha Vida (MCMV) fortaleceu a atuação das empresas de construção e incorporação residencial, de modo a permitir a ampliação da sua escala de atuação e do seu público-alvo. A centralização e a concentração de capital reestruturaram a ação do setor imobiliário, e o domínio da lógica financeira sobre a produção do espaço urbano reforçou seu papel como forma contemporânea de acumulação capitalista, ampliando seus impactos socioespaciais (Hoyler, 2016; Lencioni, 2014; Shimbo, 2016).

Entende-se que o cenário de financeirização do setor imobiliário, resumidamente apresentado, reforça a necessidade de se estudar a produção do espaço nas cidades brasileiras. Segundo Aalbers (2017), apesar de a habitação ter entrado no circuito neoliberal (ou pós-fordista) mundial, sua produção e financiamento ainda possuem amarras com o Estado, e seu processo de financeirização ocorre de forma variada e específica em diferentes países. Visando contribuir com tal debate, este artigo apresenta os resultados da pesquisa de mestrado intitulada Agentes, produtos e implicações da produção imobiliária de habitação multifamiliar em Curitiba, 2010-2018 (Martins, 2020). 0 estudo identificou e caracterizou a produção habitacional multifamiliar realizada na cidade e elencou os principais agentes do mercado que atuaram em Curitiba no período recente. Ainda, considerando as mudanças no cenário econômico ao longo da década, a pesquisa buscou compreender a lógica de atuação das empresas, especialmente na configuração dos produtos imobiliários, entendidos como estratégias para potencializar seu lucro. Também foram avaliadas as consequências socioespaciais da produção realizada.

Este texto está estruturado em quatro partes: inicia com a revisão de literatura sobre a produção do espaço (e da habitação) como mercadoria no capitalismo financeiro, debate que permeia o conteúdo do artigo; em segui$\mathrm{da}$, são descritos a metodologia e o contexto do estudo, ou seja, a cidade de Curitiba; na sequência, são apresentados os principais resultados da pesquisa, contemplando as características da produção imobiliária e da atuação dos agentes do setor ao longo do período investigado, bem como as análises sobre o espaço resultante. Por fim, são trazidas reflexões sobre a produção do espaço a partir do trabaIho realizado.

\section{A produção do espaço no capitalismo contemporâneo}

A transição do capitalismo industrial para o financeiro, iniciada no final do século $X X$, trouxe um novo papel às cidades como espaços de 
reprodução do capital. A expansão para novos mercados e a internacionalização dos processos econômicos resultaram em uma disputa para dinamizar territórios urbanos e atrair o capital global, predominantemente financeiro. A ação estatal reorganizou-se, desmontando políticas de bem-estar social em função da nova agenda econômica. A maior mobilidade do capital e as reformas neoliberais aproximaram os circuitos financeiro e imobiliário, e a urbanização ganhou escala e influência no desenvolvimento capitalista, provocando um movimento de reestruturação da produção imobiliária (Harvey, 2005; Pírez, 2018). Nas últimas décadas, o financiamento habitacional destacou-se como a dívida privada que mais cresceu em relação ao PIB mundial, o que reforça a importância do mercado de habitação na economia financeirizada (Aalbers, 2017).

Para Montes Ruiz e Durán Segura (2018), a conexão entre o neoliberalismo e as transformações urbanas é visível na promoção de novos estilos de vida, no fortalecimento do mercado imobiliário e na multiplicação de intervenções nas cidades. Nesse contexto, o setor imobiliário deixou de estar relacionado à preservação e à reserva de valor e passou a ser "um campo de investimentos com elevada rentabilidade", que comanda o processo de construção da cidade, subordinando o espaço ao capital (Pereira, 2011, p. 29). A busca por potencializar os ganhos na produção imobiliária encontra estratégias como maior velocidade de comercialização; elevação de preços através de marketing; atração ou empréstimo de capitais para alavancar negócios e realização de valores especulativos no mercado.

No Brasil, tal cenário começou a se viabilizar com a criação do Sistema de Financiamento Imobiliário (SFI) em 1997, delineado com o objetivo de regulamentar e fortalecer o mercado de títulos imobiliários e desburocratizar a concessão de crédito ao setor (Royer, 2016). Fez parte desse processo o movimento de concentração e centralização de capital das empresas construtoras e incorporadoras, via fusões, aquisições e participação de fundos internacionais, o que caracteriza uma reestruturação nesse campo e um novo patamar de acumulação de capital. Com a financeirização, as grandes empresas formaram bancos de terras, expandiram sua atuação para diversas cidades do País e aumentaram seu poder de produzir e difundir novos produtos e espacialidades, de acordo com a necessidade de reprodução do capital (Lencioni, 2014; Rolnik, 2015; Rufino, 2012).

O alinhamento de interesses, a sobreposição de relações entre os agentes públicos e privados e a interdependência entre mercado imobiliário e finanças configurou, a partir dos anos 2000, "um 'complexo imobiliário-financeiro' na produção de habitação no Brasil" (Shimbo, 2016, p. 132). A abertura de capital de diversas empresas de construção e incorporação e o contexto econômico favorável, que estimulou a retomada do crédito imobiliário, levaram o mercado formal de habitação a "descobrir" um novo perfil de consumidores. O segmento econômico, até então pouco atrativo para as empresas do setor, multiplicou-se, e diversas construtoras criaram marcas exclusivas para atuar nessa fatia do mercado (Hoyler, 2016; Shimbo, 2016). Para aumentar a capacidade produtiva e as margens de lucro, a estratégia das empresas nesse período passou por "racionalização da produção" e "padronização dos empreendimentos imobiliários", além de mesclar "diversificação dos segmentos" e "expansão geográfica" (Rufino, 2012, pp. 75-76). 
A partir de 2009, a execução do Programa Minha Casa Minha Vida (MCMV) ampliou o acesso a recursos públicos subsidiados para o financiamento da habitação. Proposto pelo governo federal como uma medida anticíclica após a crise financeira mundial, o MCMV manteve a lógica da habitação como mercadoria e alavancou ainda mais o segmento econômico no ramo imobiliário. 0 programa habitacional, costurado entre Estado e construtoras para fomentar a economia e gerar empregos, liberou um alto volume de recursos públicos para a produção e venda de habitação para as camadas de baixa renda pelo mercado e resultou em lucro imediato para as empresas, cujas ações se recuperaram da queda na bolsa após a crise de 2008. No entanto, apesar da ampla divulgação da política habitacional, apenas a produção referente à faixa 1 do MCMV correspondia à Habitação de Interesse Social (HIS). Ainda, a atuação do setor privado no programa manteve a base produtiva de baixa tecnologia e a dependência de subsídios públicos (Rolnik, 2015; Shimbo, 2016).

Nos empreendimentos destinados às faixas 2 e 3 do MCMV, a definição dos projetos era feita pelas empresas a partir de estudos de viabilidade, considerando o valor máximo de financiamento por unidade habitacional definido no programa. Quanto mais unidades produzidas e mais barato o terreno, maior o lucro. Nessa lógica, a principal solução adotada foram os condomínios fechados, verticais ou horizontais, localizados em terrenos baratos e distantes. Esse padrão de atuação, além de definir e elevar os preços dos terrenos em algumas regiões, produziu efeitos negativos no espaço urbano, pela localização, escala, monofuncionalidade e homogeneidade social dos empreendimentos, que não modificaram o lugar periférico tradicionalmente ocupado pela população de baixa renda nas cidades (Rolnik, 2015; Shimbo, 2016).

Para Pereira (2011), os novos produtos imobiliários, independentemente de seu público-alvo, são configurados para maximizar a reprodução do capital, o que aumenta sua quantidade, valor e tamanho e transforma as metrópoles contemporâneas em aglomerações dispersas e fragmentadas, alterando o padrão centro-periferia da urbanização industrial. Conforme crescem os negócios imobiliários, aumenta a proporção da população que não se beneficia deles. Segundo o autor, apesar de a moradia estar aparentemente mais acessível, os mecanismos de financiamento e a adoção da propriedade condominial em produtos para todas as faixas de renda aumentam a segregação espacial e incorporam áreas cada vez mais distantes do tecido urbano, ofertando casa, mas não experiência citadina.

O papel do Estado não pode ser negligenciado nesse processo, já que recursos e subsídios obtidos via fundos públicos financiaram a expansão do setor e garantiram lucros recordes aos capitais imobiliário e fundiário, visíveis na intensa valorização dos imóveis no País na última década. Ao mesmo tempo, o consumo da produção habitacional via financiamento se transformou em dívida para os compradores (Lencioni 2014; Tone, 2010). Nas cidades latino-americanas, onde grande parte da urbanização do período industrial ocorreu à margem do mercado e Estado, as reformas neoliberais resultaram em "intervenções estatais destinadas a fortalecer os processos de produção-consumo mercantil" (Pírez, 2018, p. 53, tradução nossa). Essas constatações 
demonstram que "o vínculo entre habitação (housing) e mercado imobiliário (real estate)" se tornou ainda mais forte no capitalismo contemporâneo (Shimbo, 2016, p. 131).

\section{Metodologia e contexto da pesquisa}

Curitiba é polo de uma região metropolitana composta por 29 municípios, e sua a Área de Concentração de População (ACP), definida pelo IBGE, corresponde aos 14 municípios que de fato constituem uma mancha urbana contínua, abrigam deslocamentos cotidianos e concentram grande parte da população. Um estudo recente do Observatório das Metrópoles sobre a dinâmica imobiliária na região constatou o crescimento da verticalização em Curitiba e o surgimento de empreendimentos para os segmentos de média e alta renda nos municípios vizinhos, sem, no entanto, alterar o padrão de periferização da população mais pobre. As tendências de densificação no polo e dispersão pelo espaço metropolitano ocorrem de forma simultânea, e foi identificado o aumento da fragmentação territorial na metrópole, consequência da implantação de espaços de moradia e de atividades econômicas em áreas periféricas (Firkowski e Moura, 2014).

Trabalhos anteriores destacam a relevância da atuação do mercado imobiliário na produção do espaço urbano em Curitiba. ${ }^{1}$ No entanto, o período recente, que engloba o boom imobiliário e a execução do programa MCMV, bem como a recessão dos anos 2015/2016, não foi avaliado localmente. Assim, a pesquisa aqui apresentada (Martins, 2020) se propôs a investigar a produção de habitação pelo mercado na última década, com o objetivo de avaliar o processo em si - os agentes envolvidos, a lógica do mercado e a formatação dos produtos imobiliários - e suas implicações socioespaciais. Para tanto, foi analisada a produção imobiliária de habitação multifamiliar concluída em Curitiba entre os anos de 2010 e 2018, incluindo os empreendimentos das faixas 2 e 3 do programa MCMV, ${ }^{2}$ com menores subsídios e comercializados pelo setor privado. Partiu-se da hipótese de que o mercado imobiliário, ao definir os produtos habitacionais e sua distribuição em diferentes localizações urbanas, é o principal responsável pela produção do espaço da cidade e por sua apropriação por grupos sociais distintos. Supôs-se, também, que a escala da sua atuação se alterou, tendo em vista a financeirização do setor e a política habitacional instituída pelo governo federal - entendida como parte do processo de financeirização da moradia no Brasil, a partir do raciocínio de Aalbers (2017). O intervalo de tempo pesquisado foi considerado relevante por abranger a atuação de grandes empresas do setor e a conclusão de boa parte da produção do MCMV na cidade. Ainda, o período inclui momentos de expansão e retração do mercado imobiliário, o que permite identificar mudanças na estratégia dos agentes conforme a conjuntura econômica.

Foram passos metodológicos (ou objetivos específicos) da pesquisa: (1) quantificar e caracterizar a produção imobiliária do período; (2) identificar as principais empresas construtoras e/ou incorporadoras que atuaram na cidade; (3) classificar e espacializar os produtos imobiliários; (4) observar a estratégia das empresas ao longo da década; e (5) avaliar as implicações socioespaciais da produção realizada. Para esta última etapa foram realizadas 
análises espaciais, na escala municipal, considerando os produtos habitacionais, o Índice de Vulnerabilidade Social (elaborado pelo Ipea) e os preços dos imóveis novos, por bairro, nos anos de 2010, 2014 e 2018 (conforme dados do Inpespar - Instituto Paranaense de Pesquisa e Desenvolvimento do Mercado Imobiliário e Condominial). Para a visualização do espaço urbano resultante, foram detalhadas, em mapas e imagens, algumas áreas com produção intensa no período, indicando a estrutura urbana (limite de bairros, rede estrutural de transporte, equipamentos urbanos), o zoneamento vigente, os empreendimentos e a sua relação com o entorno.

A principal fonte de dados foram os relatórios mensais sobre os Certificados de Vistoria de Conclusão de Obra (CVCO) emitidos pela Secretaria Municipal de Urbanismo (SMU) nos anos de 2010 a 2018. A partir das informações disponíveis nesses relatórios, foi definido o universo da pesquisa: ${ }^{3} 1.115$ empreendimentos de habitação multifamiliar que somam 76.510 unidades habitacionais (UH). Complementarmente, foi feita uma investigação em periódicos da época e nos sites das principais construtoras. As notícias e propagandas encontradas auxiliaram na identificação dos promotores dos empreendimentos, na classificação dos produtos imobiliários e na compreensão da estratégia de atuação das empresas.

Por fim, cabe ressaltar que o estudo da produção imobiliária de habitação em Curitiba é um recorte na discussão mais ampla sobre a produção do espaço metropolitano. A escolha do objeto justifica-se pela importância da moradia para os cidadãos e por seu papel relevante na "expansão e estruturação da metrópole" (Baliski, 2019, p. 30). Ainda, compreender a atuação do setor imobiliário auxilia o entendimento de outros processos, não mercantis, de produção e/ou apropriação do espaço urbano/metropolitano (Volochko, 2011).

\section{Produção imobiliária habitacional em Curitiba: ciclos, agentes e produtos}

Uma das primeiras constatações sobre a produção de habitação multifamiliar em Curitiba diz respeito à distribuição das unidades concluídas por ano, dado que reflete os diferentes momentos do setor de construção civil no período 2010-2018. A fase com grande produção de imóveis residenciais no Brasil, iniciada após a crise de 2008, teve seu auge entre os anos de 2010 e 2012, e, em 2014, ocorreu o pico de financiamentos imobiliários no País em número de unidades e em volume financeiro - aliado à sucessiva valorização dos preços de comercialização (ZAP, 2016).

Em Curitiba, esse movimento se reflete de maneira clara nos CVCOs emitidos por ano, com o número de unidades finalizadas em 2013 e 2014, sendo mais de três vezes superior ao dos anos de 2010 e 2018. Do total de unidades produzidas no período estudado 76.510 UH -, 36\% foram concluídas nos anos de 2013 e 2014, o que demonstra a concentração de lançamentos imobiliários habitacionais no início da década, considerando-se o tempo médio de duração das obras (Martins, 2020).

Além da quantidade de unidades produzidas, outro dado relevante é o grande porte dos empreendimentos realizados na primeira metade da década (ibid.), especialmente pelas incorporadoras com atuação nacional, 
Gráfico 1 - Unidades habitacionais multifamiliares verticais concluídas em Curitiba - 2010-2018

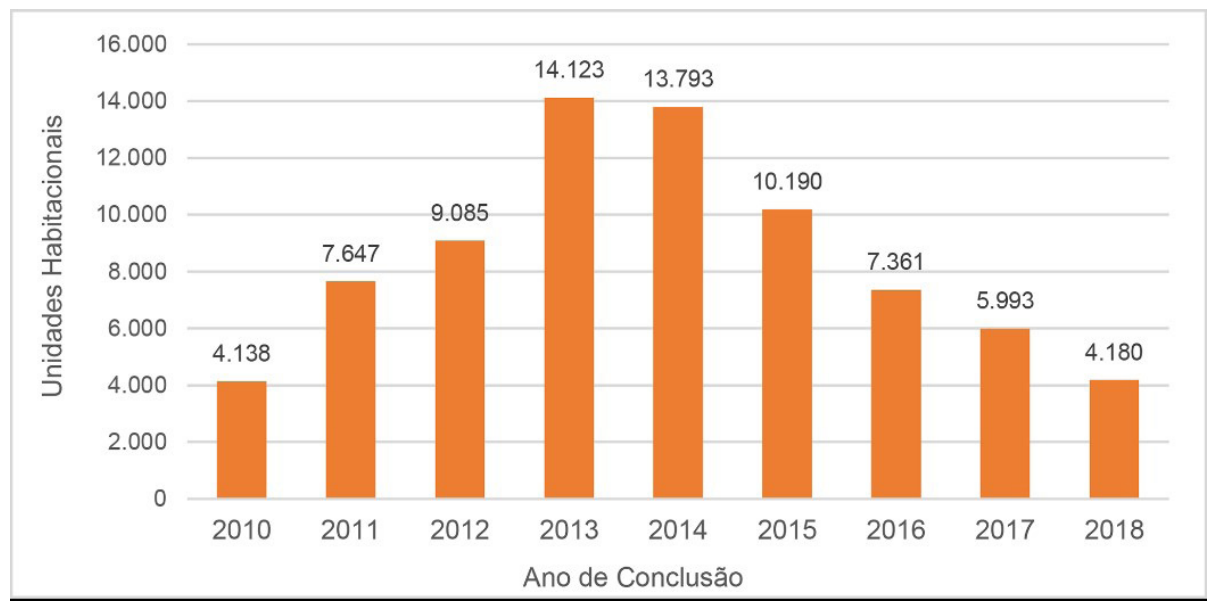

Fonte: Martins (2020).

que possuem força para lançar tendências e modificar o mercado local. A escala dos empreendimentos foi parte da estratégia adotada pelas empresas durante o boom da construção civil, visando a aumentar sua receita, atender a alta demanda e atingir o crescimento esperado pelos investidores. Essa solução impactou na morfologia da produção imobiliária do período (Alas, 2013; Rufino, 2012). Em Curitiba, a média de unidades habitacionais por empreendimento concluído no ano de 2013 foi de $88 \mathrm{UH}$, praticamente o dobro das médias em 2010 e 2018 (45 e 46 UH, respectivamente).

A partir de 2013, a instabilidade política e econômica começou a desacelerar o crescimento do setor. Somadas ao cenário econômico desfavorável, mudanças nas regras de financiamento reduziram a demanda do mercado, o que fez com que o reajuste no valor dos imóveis ficasse abaixo da inflação no ano de 2015 (ZAP, 2016). Essa mudança do cenário econômico provocou mudanças nas características dos produtos e dos agentes responsáveis pela produção habitacional. Mioto, Castro e Sígolo (2019), em seu estudo sobre a dinâmica imobiliária na Região Metropolitana de São Paulo, observaram que a crise na economia gerou uma forte queda na produção imobiliária a partir de 2014, gerando capacidade ociosa, devolução de imóveis e retorno da produção aos mercados consolidados. Nas empresas capitalizadas, a fragilidade financeira e o alto endividamento levaram à redução dos investimentos.

De maneira alinhada ao constatado pelas autoras, observou-se, em Curitiba, que a produção das empresas de capital aberto foi fortemente concentrada na primeira metade da 
década, com a conclusão das obras até o ano de 2015. A partir desse mesmo ano, é visível a modificação no porte dos empreendimentos concluídos em Curitiba, refletindo as mudanças decorrentes do desaquecimento do mercado. Enquanto no período entre 2011 e 2014 os projetos finalizados com até 200 unidades habitacionais estão dentro do padrão normal ${ }^{4}$ observado, o valor cai para a metade - 100 unidades - no período entre 2015 e 2018, o que demonstra a menor capacidade de investimento das empresas e a opção por produtos de menor risco no período de crise (Martins, 2020).

Como exemplo do perfil da produção e dos agentes na fase expansiva do mercado, verificou-se que, ao longo do período 2010-2018, foram concluídos, na cidade, 25 empreendimentos com mais de 400 apartamentos, que somaram 14.027 unidades, sendo 64\% deles finalizados até 2014 e $80 \%$ até o ano de 2015 . Dos 25 projetos, 16 foram produzidos por empresas com capital aberto na Bovespa e 9 foram empreendimentos do programa MCMV; apenas 3 deles, realizados pela MRV, encontram-se nas duas categorias.
Os 3 projetos restantes foram produzidos por (1) Thá, empresa regional administrada na época por um fundo financeiro internacional; (2) AK Realty, grupo de São Paulo com sólida atuação no setor; e (3) Canet Junior, um forte grupo empresarial local (ibid.).

Com relação às empresas que atuaram em Curitiba, a pesquisa buscou encontrar as principais responsáveis pela produção do período e verificar semelhanças e diferenças na sua atuação, conforme o perfil da companhia. Das 250 empresas identificadas, mais da metade teve uma produção pequena, de até 100 unidades habitacionais concluídas entre 2010 e 2018 . Além disso, $62 \%$ das unidades habitacionais concluídas no período foram realizadas por 32 empresas (que correspondem a 13\% do total), sendo um terço dos 76.510 apartamentos produzido por apenas 7 empresas, em 118 empreendimentos diferentes (média de 214 UH por projeto). Constata-se, assim, no período estudado, a concentração da produção imobiliária de Curitiba em algumas incorporadoras, bem como o maior porte dos projetos por elas executados (Tabela 1).

Tabela 1 - Empresas por unidades habitacionais (UH) multifamiliares concluídas

\begin{tabular}{|c|c|c|c|c|c|c|}
\hline Produção 2010-2018 & $\begin{array}{c}\text { № de } \\
\text { empresas }\end{array}$ & $\begin{array}{l}\text { Empreendimentos } \\
\text { E }\end{array}$ & UH & $\begin{array}{l}\text { Média } \\
\text { UH/E }\end{array}$ & $\begin{array}{c}\text { \% Total } \\
\text { UH }\end{array}$ & $\begin{array}{c}\% \text { Total } \\
\text { empresas }\end{array}$ \\
\hline até 100 UH & 142 & 197 & 5.465 & 28 & 7 & 57 \\
\hline $101-500 \mathrm{UH}$ & 76 & 291 & 15.758 & 54 & 21 & 30 \\
\hline $501-1.000 \mathrm{UH}$ & 19 & 110 & 13.395 & 122 & 18 & 8 \\
\hline $1.001-2.000 \mathrm{UH}$ & 6 & 46 & 9.171 & 199 & 12 & 2 \\
\hline$>2.000 \mathrm{UH}$ & 7 & 118 & 25.219 & 214 & 33 & 3 \\
\hline sem informação & & 353 & 7.502 & 21 & 10 & \\
\hline Total & 250 & 1.115 & 76.510 & 69 & 100 & 100 \\
\hline
\end{tabular}

Fonte: Martins (2020); formatado pelas autoras em 2021. 
Dentre as 7 empresas que produziram mais de 2.000 unidades em Curitiba no período de 9 anos, 5 possuem capital aberto, MRV, PDG, Gafisa, Cyrela e Rossi; e outras duas possuem forte atuação regional, Plaenge e Thá. Em 2012, o grupo Thá teve $80 \%$ de seu controle vendido pela família para o fundo Equity International, do investidor Sam Zell, fato que ressalta a articulação entre agentes financeiros e imobiliários no período. ${ }^{5}$ Algumas dessas empresas possuem marcas diferentes para atuação em nichos de mercado, como Cyrela/Living, Gafisa/Tenda e Plaenge/ Vanguard Home. A construtora que mais produziu na cidade, entre 2010 e 2018, foi a MRV, com 6.446 unidades distribuídas em 30 projetos (Martins, 2020).

A financeirização de empresas em ramos tradicionalmente "não financeiros" é um dos temas a ser aprofundado no debate sobre a financeirização da habitação. 0 fato de as incorporadoras de capital aberto utilizarem o mercado de capitais como fonte de financiamento inclui uma mudança na forma de condução dos seus negócios, que passa a ter como foco a visão do acionista (Aalbers, 2017). A preponderância da lógica financeira leva à busca por resultados crescentes, através da expansão da produção para novas faixas de renda e em novos mercados no País (Sígolo, 2014; Tone, 2010). No período de expansão do setor, além do grande volume de lançamentos, as principais construtoras padronizaram parâmetros de construção, de arquitetura, de custo e de preço dos imóveis, conforme modelos e nichos de mercado específicos (Mioto, Castro, Sígolo, 2019).

Destaca-se que 11 empresas com capital aberto na Bovespa atuaram em Curitiba no período estudado: MRV, PDG, Gafisa, Tenda, Cyrela, Rossi, Tecnisa, Brookfield, CCDI, Abyara e Helbor. ${ }^{6}$ Juntas, elas produziram 24.803 unidades, 32\% do total produzido entre 2010 e 2018. Em diversos casos, a atuação dessas empresas contou com a parceria de agentes locais. São exemplos a joint venture firmada em 2007 entre a PDG e a LN Empreendimentos Imobiliários, que resultou na venda do grupo local para a PDG em 2010; a parceria no período 20072015 entre a Cyrela, a Goldstein e a Dória, atual MDGP, de Curitiba; e a associação entre a incorporadora Helbor, de São Paulo, e a RA Empreendimentos, local. Outro caso é a parceria iniciada em 2006 entre as incorporadoras Monarca, de Curitiba, e Stuhlberger, paulista, que, por sua vez, mantém uma joint venture com a construtora Tecnisa (Martins, 2020). Essas estratégias corroboram a leitura de Lencioni (2014) sobre a reestruturação do setor imobiliário, reflexo da reestruturação do próprio capitalismo para garantir sua reprodução.

Para aprofundar a análise sobre a atuação das empresas e a produção do espaço em Curitiba, entendeu-se ser necessário separar em diferentes produtos imobiliários os 1.115 projetos multifamiliares concluídos entre 2010 e 2018. Dessa forma, foi elaborado um critério de classificação com os dados disponíveis nos relatórios mensais de CVCOs. Destaca-se que a elaboração dessa classificação foi uma etapa importante do processo de pesquisa, pois permitiu visualizar as estratégias de atuação das empresas e a lógica utilizada na localização dos diferentes produtos habitacionais. As informações usadas para definir a categoria dos empreendimentos foram: (1) total de unidades habitacionais, (2) número de blocos do projeto e (3) fração adquirida ${ }^{7}$ (ou área total) de cada unidade. A partir desses elementos, foram identificados oito produtos imobiliários que caracterizam a atuação do mercado no período 
(Martins, 2020): Multiuso; Compacto; Popular de Pequeno Porte; Habitação Social de Mercado, conforme conceito de Shimbo (2016); Condomínio-Clube; Médio Padrão; Alto Padrão e Altíssimo Padrão. A categoria Baixo Impacto, não necessariamente produzida por agentes de mercado, foi considerada pouco relevante para a análise realizada (Figura 1).

Figura 1 - Classificação dos empreendimentos em produtos imobiliários Curitiba, 2010-2018

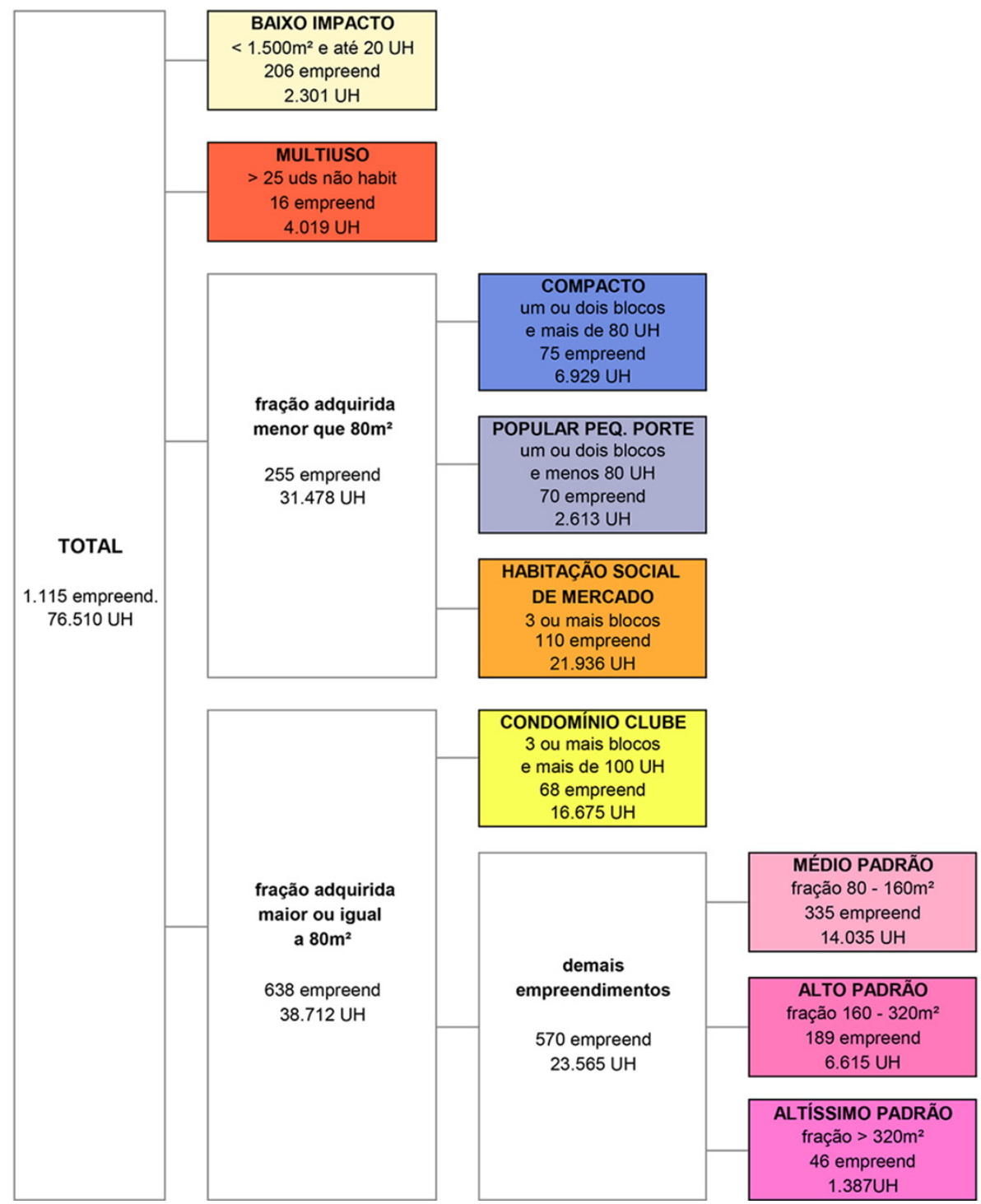

Fonte: Martins (2020). 
Dentre os produtos imobiliários identificados, foram considerados "tradicionais" os edifícios com uma ou duas torres voltados aos segmentos popular, médio, alto e altíssimo padrão. Os produtos considerados "inovações" no período são os projetos de grande porte, que demandam mais capital para sua realização: Multiuso, Condomínio-Clube e Habitação Social de Mercado (HSM). Também foram incluídos no nicho "inovação" os edifícios com apartamentos Compactos, alternativa adotada pelo mercado em face da crise no setor, já que a pequena metragem dos imóveis - do tipo studio - reduz o valor final de comercialização, apesar do nem sempre baixo valor por $\mathrm{m}^{2}$. Esses projetos contam com ampla oferta de áreas comuns, como salão de festas, lavanderia, academia, piscina, rooftop, espaço gourmet, coworking e bicicletário, entre outros (ibid.).

Cabe mencionar que os empreendimentos das faixas 2 e 3 do programa MCMV foram classificados na pesquisa conforme suas características, não sendo necessariamente enquadrados como Habitação Social de Mercado (HSM), apesar de a maioria assim se revelar. Dos 99 condomínios verticais concluídos pelo MCMV em Curitiba no período estudado, $75 \%$ apresentam alto número de unidades e de blocos de apartamentos, sendo classificados como HSM. Cerca de 10\% caracterizam-se como Popular de Pequeno Porte e outros 10\% são edifícios com apartamentos Compactos, que, apesar das dimensões reduzidas, não se destinam, necessariamente, ao público-alvo do programa. Seguindo a mesma lógica, alguns empreendimentos não oficialmente pertencentes ao MCMV foram considerados como HSM na pesquisa, devido às suas especificidades e ao seu público-alvo. ${ }^{9}$

A distribuição das unidades habitacionais entre os produtos imobiliários pode ser observada no Gráfico 2. Destaca-se que, dos 76.510 apartamentos finalizados em Curitiba entre 2010 e 2018, metade está nos produtos Condomínio-Clube e Habitação Social de Mercado.

Gráfico 2 - Distribuição das unidades habitacionais conforme classificação Curitiba, 2010-2018

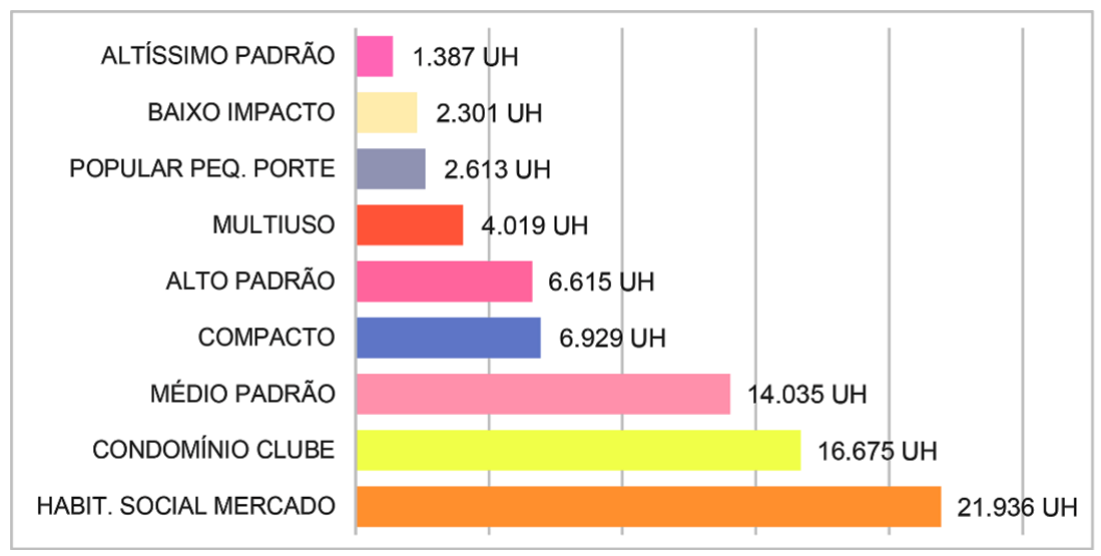

Fonte: Martins (2020); formatado pelas autoras em 2021 
Entre as empresas de capital aberto, essas duas categorias somam $70 \%$ dos projetos executados e $78 \%$ dos apartamentos entregues.

Gráfico 3 indica o número médio de unidades dos produtos imobiliários finalizados em Curitiba, e é expressivo o maior porte dos produtos inovadores. O elevado número de apartamentos e blocos em alguns projetos evidencia a padronização da habitação e permite intuir o impacto desses condomínios no tecido urbano, tanto pela dimensão dos terrenos como por sua localização. Mais da metade dos Condomínios-Clube e produtos de HSM produzidos na cidade possui 6 blocos ou mais, chegando a mais de 30 em alguns projetos do MCMV (ibid.).

A preferência dos agentes financeirizados pelos produtos "inovadores", divulgados como novidade no mercado local, não foi exclusividade de Curitiba. Conforme as pesquisas de Rufino (2012) e Tone (2010) em Fortaleza e
São Paulo, no período de expansão do setor a atuação das principais construtoras e incorporadoras combinou redução de custos na produção, aumento na escala dos empreendimentos e valorização das unidades, pela grande oferta de áreas de lazer. Mas, ao mesmo tempo que o marketing imobiliário vendia exclusividade, havia uma padronização dos projetos (Rufino, 2012; Tone, 2010).

Além do Condomínio-Clube e da Habitação Social de Mercado, outro produto com destaque entre as empresas capitalizadas é o Multiuso, no qual os empreendimentos mesclam unidades habitacionais com outros usos, como escritórios e hotelaria. Em Curitiba, os apartamentos em projetos Multiuso representam $10 \%$ do total produzido por esses agentes e se concentram no centro da cidade. Especificamente sobre os produtos Multiuso e Compacto, ressalta-se o seu aspecto positivo de ofertar mais habitação na área central, bem

Gráfico 3 - Porte dos produtos imobiliários (média UH/empreendimento) Curitiba, 2010-2018

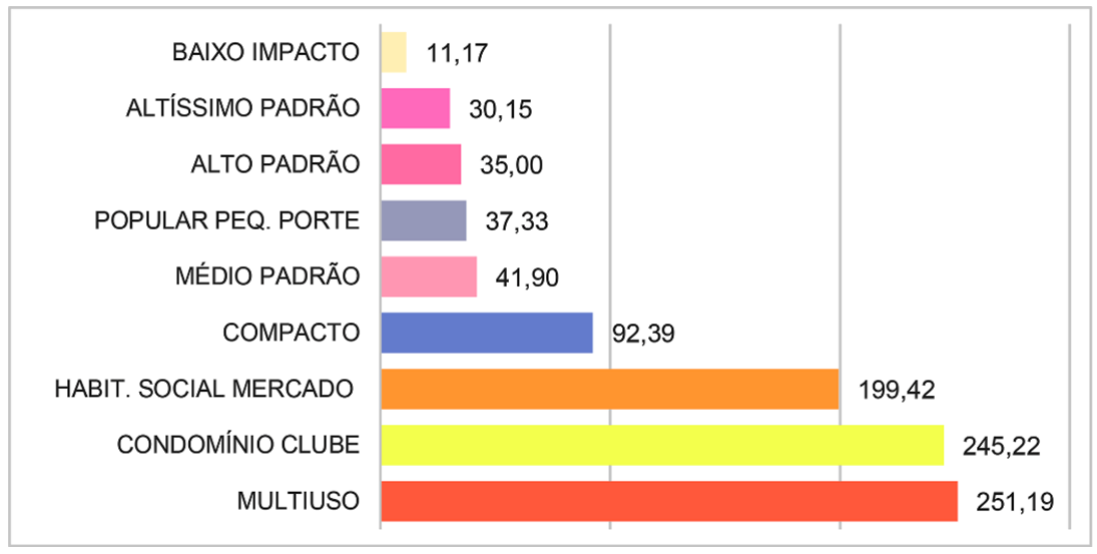

Fonte: Martins (2020); formatado pelas autoras em 2021. 
servida por empregos, infraestrutura, equipamentos e transporte. No entanto, a metragem reduzida das unidades, a presença de espaços de uso comum sofisticados e o alto custo por metro quadrado desses imóveis limitam sua aquisição a um público específico, composto por jovens solteiros, casais sem filhos ou investidores pensando em aluguel de curta temporada, dificultando seu acesso por famílias de menor renda (Martins, 2020).

Apesar da identificação de diferentes produtos habitacionais em Curitiba, o processo de pesquisa mostrou que os projetos são muito parecidos entre si e apenas alguns aspectos alteram o seu público-alvo, sendo a localização um dos principais. Segundo Abramo (2007), a estratégia do setor imobiliário passa pela inovação nos lançamentos de alto padrão e sua reprodução adaptada para as demais faixas de renda, com os produtos incorporando os novos desejos de consumo. Como exemplo, citam-se características similares nos produtos Condomínio-Clube e Habitação Social de Mercado, condomínios verticais implantados em terrenos grandes, com opções de lazer como atrativo e elevado número de unidades. As áreas privativas dos apartamentos são muito próximas e a diferença na fração adquirida depende basicamente se as áreas destinadas às garagens e aos usos comuns são computáveis, ou seja, cobertas. Outra alteração é o padrão de acabamento dos edifícios e das áreas comuns. No caso dos produtos de Médio/Alto Padrão e do Condomínio-Clube, a principal diferença é o porte dos projetos. Já, entre empreendimentos Multiuso e Compactos, a mudança é a presença de atividades não habitacionais no conjunto (Martins, 2020). Mesmo com suas semelhanças, todos os produtos são divulgados como portadores de qualidades únicas e exclusivas.
A produção da moradia pelo mercado financeirizado resulta, segundo Tone (2010, p. 77), na "generalização da produção de grandes condomínios verticalizados" e na reprodução da "forma-condomínio por segmento de renda" como elemento de reestruturação e segregação do espaço urbano. Para a autora, a produção crescente de condomínios verticais padronizados, definidos conforme faixa de renda, tornou-se um modo de hierarquizar e segregar o espaço, já que um maior retorno financeiro envolve a articulação entre produto, valorização e segregação espacial. Essa equação fica visível ao se observar a distribuição dos diferentes produtos identificados na cidade de Curitiba (Figura 2).

A localização dos produtos habitacionais demonstra que a lógica do mercado reforçou a segmentação socioespacial na cidade. Ao mesmo tempo que a atuação do setor promove a concentração dos produtos de Alto e Altíssimo Padrão em regiões consolidadas e com melhores indicadores sociais, também promove a extensão dessas áreas de "distinção espacial"10 para os bairros contíguos. De maneira oposta, os produtos de Habitação Social de Mercado, salvo poucas exceções, estão em áreas afastadas do centro e com maior vulnerabilidade social. ${ }^{11}$ Chama a atenção a concentração de produtos financiados pelo programa MCMV nos extremos norte e sul do município, em regiões com altos indicadores de vulnerabilidade e distantes dos principais terminais de transporte urbano. Também se destaca a produção significativa realizada na região central da cidade, com predominância dos projetos Multiuso e Compactos; e na área da Operação Urbana Consorciada Linha Verde, ${ }^{12}$ eixo de transporte e adensamento junto à antiga rodovia BR-116, na qual foram implantados 
Figura 2 - Localização dos produtos imobiliários conforme classificação Curitiba, 2010-2018

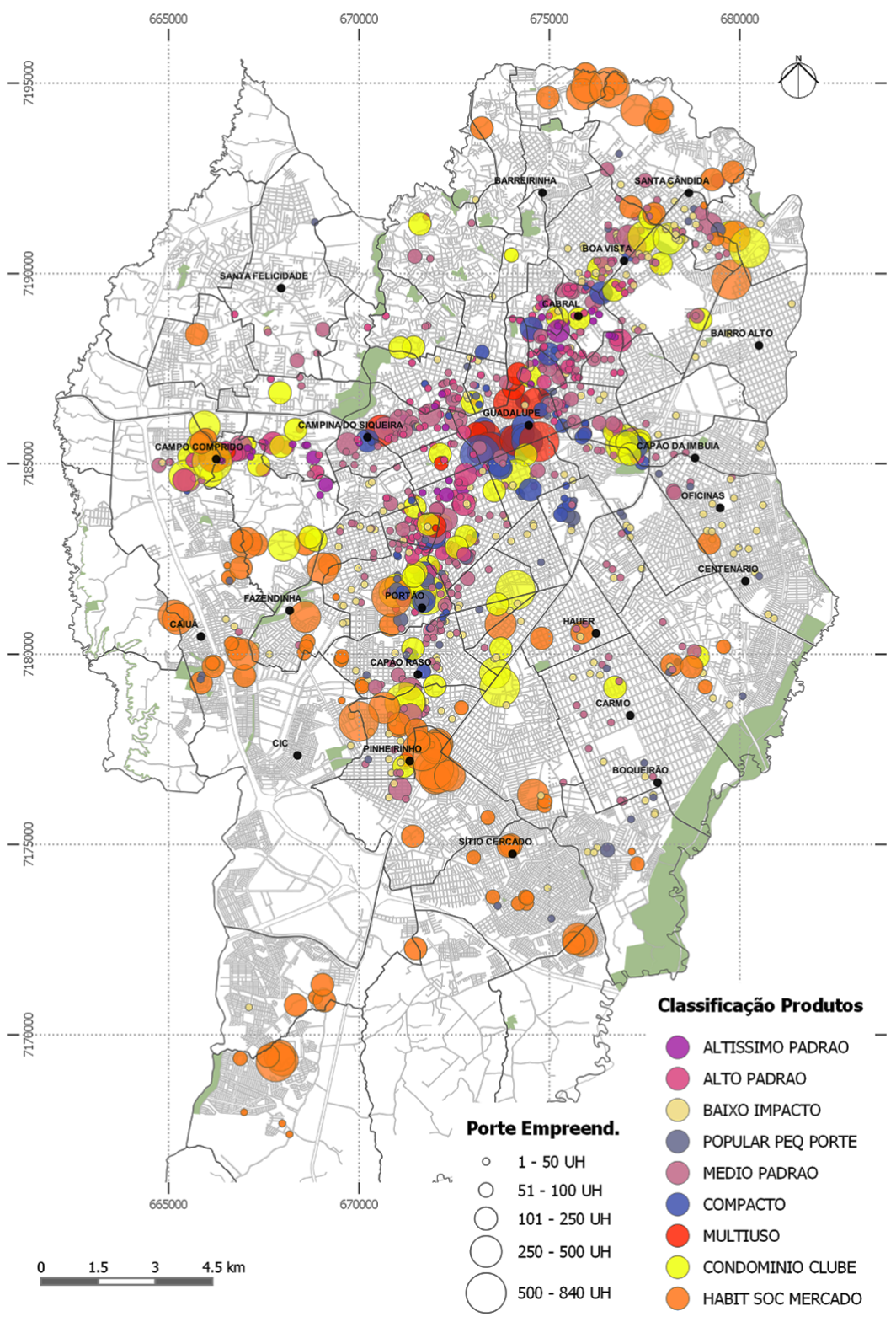

Fonte: Martins (2020). 
diversos Condomínios-Clube e projetos de Habitação Social de Mercado, estes últimos com maior concentração no Setor Sul da Operação Urbana (Martins, 2020).

A pesquisa constatou que as frentes de atuação do mercado imobiliário em Curitiba, no período 2010-2018, foram similares às identificadas por Rufino (2012) em Fortaleza, com quatro movimentos principais: (1) intensificação da apropriação dos espaços valorizados da cidade, reforçando a diferenciação dessas áreas, caso dos bairros Campina do Siqueira e Mossunguê (próximos ao parque Barigui) e Cristo Rei (ao lado do Jardim Botânico); (2) expansão das áreas de valorização, pela atuação no prolongamento das regiões valorizadas, estendendo o seu padrão de ocupação, como nos bairros Campo Comprido e Cidade Industrial (continuação do "Ecoville"), Portão (extensão do eixo Batel-Água Verde) e Boa Vista/Bacacheri (expansão do Cabral); (3) criação de novas áreas de valorização, especialmente para a produção do segmento econômico, levando a atuação do mercado formal para regiões periféricas ou pouco exploradas da cidade, situação observada, por exemplo, nos bairros Pinherinho (Setor Sul da OUC Linha Verde) e Santa Cândida/Cachoeira, no extremo norte da cidade; (4) redescoberta de regiões adensadas, porém estigmatizadas, através da inserção de produtos voltados para um público diverso do atual, em que se destaca a produção realizada na área central de Curitiba, especialmente na proximidade dos shoppings Curitiba, Estação e Mueller.

Separar espacialmente os produtos "tradicionais" e "inovadores" ressalta as diferenças na forma da produção financeirizada, tanto no porte quanto na localização (Figura 3). Os produtos tradicionais têm menor porte, são realizados por diversos agentes e concentram-se em áreas consolidadas da cidade, como o Setor Estrutural. ${ }^{13}$ Já os produtos inovadores, priorizados pelas grandes construtoras, avançam para áreas menos exploradas pelo mercado ou visam reorientar a ocupação de certas regiões, como no caso do Centro ou da Linha Verde. Pela dimensão e localização desses projetos, pode-se afirmar que sua implantação reforçou a fragmentação urbana e a segregação socioespacial na cidade. A inserção dos novos produtos imobiliários em áreas periféricas altera a lógica de formação de preços dessas regiões - fato observado na análise de preços dos imóveis novos em Curitiba -, e esse processo pode levar à expulsão da população local. Ainda, ao ampliar seu campo de atuação para novos públicos e novas áreas da cidade, o mercado homogeneíza a forma de morar, o que tende a alterar práticas socioespaciais preexistentes (Martins, 2020).

De maneira similar ao que foi observado em outras pesquisas (Mioto, Castro, Sígolo, 2019; Rufino, 2012; Sígolo, 2014), a expansão imobiliária habitacional para as áreas periféricas viabilizou-se pela valorização simbólica associada ao condomínio, que, nas palavras de Rufino (2012, pp. 211-212) vinculou a habitação "ao usufruto de um espaço equipado para lazer, que supostamente possibilita aos seus usuários 'qualidade de vida'”. Como é considerado um espaço à parte, o condomínio pode ser produzido em áreas com piores condições de infraestrutura e urbanização, ao mesmo tempo que estabelece um novo patamar de preço para atuação do mercado. Segundo Pereira (2011), esse modelo combina elementos de distinção e descontinuidade que ampliam a desigualdade urbana. Muito do que foi produzido em Curitiba, especialmente os produtos 
Figura 3 - Localização e porte dos produtos "tradicionais" e "inovadores" Curitiba, 2010-2018

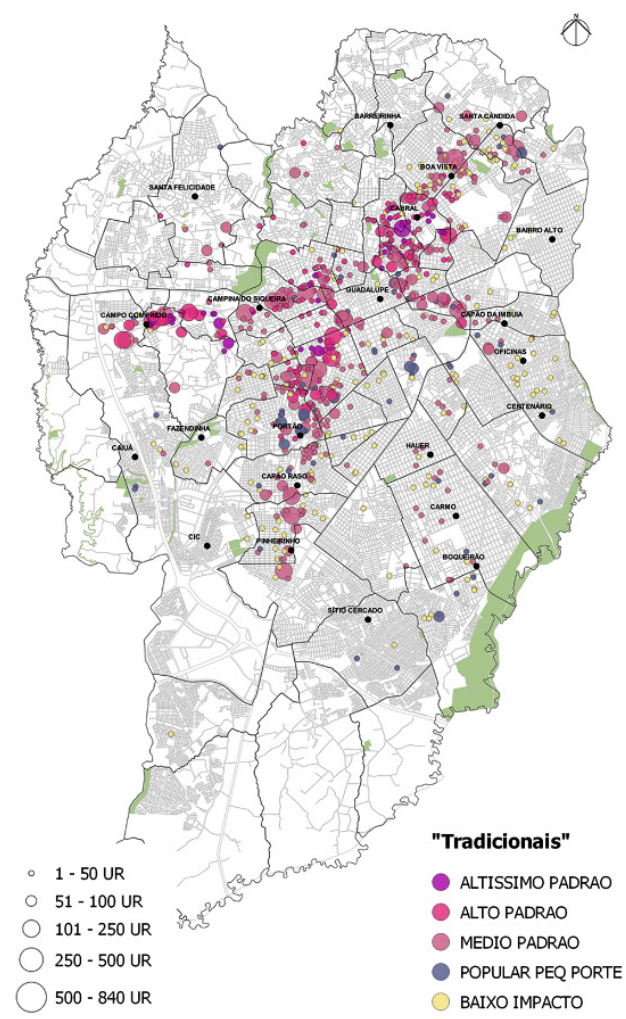

Fonte: Martins (2020); formatado pelas autoras em 2021.

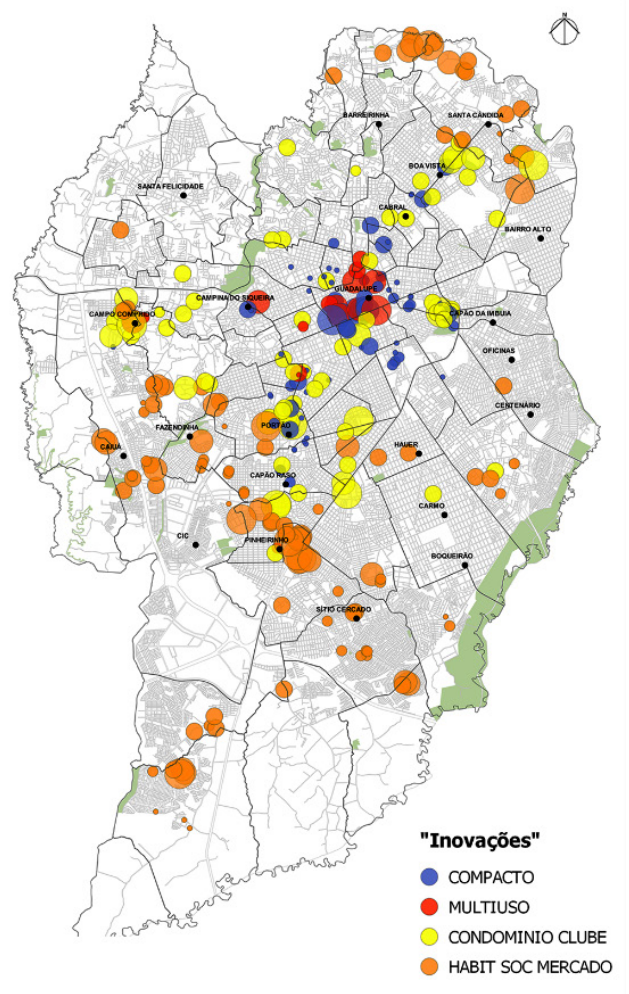

e cercados, que representam a solução mais lucrativa para o mercado dentro das regras do programa. Em algumas regiões, como nos bairros Santa Cândida e Cachoeira e no Setor Sul da Linha Verde, a implantação contígua dos empreendimentos manteve um padrão de ocupação homogêneo e sem relação com a rua em áreas extensas, impactando negativamente a paisagem e a vivência urbana (Martins, 2020). 
No caso da OUC Linha Verde, os lotes de grandes dimensões, relacionados à antiga função rodoviária da via, encaixaram-se perfeitamente à escala desejada para os condomínios verticais de Habitação Social de Mercado. Mesmo com a falta de diversidade do espaço resultante, entende-se como positiva a localização dos produtos para as faixas 2 e 3 do MCMV na região, que conta com boa oferta de infraestrutura e transporte. Já, no extremo norte da cidade, a situação é oposta. A produção ali realizada se concentrou em áreas afastadas dos principais eixos de comércio, equipamentos e transporte, e não indicadas para adensamento conforme o zoneamento vigente. Ainda assim, a prefeitura, via Companhia de Habitação Popular de Curitiba (Cohab-CT), atuou como parceira na realização dos projetos, facilitando os trâmites de aprovação e investindo em infraestrutura na região, que também recebeu empreendimentos destinados à faixa 1 do programa (ibid., 2020).

A oferta de crédito e os subsídios públicos mantiveram o preço da moradia elevado, e muitas famílias comprometeram parte de sua renda para o ingresso no mercado formal de habitação (Sígolo, 2014). Importante ressaltar que a aquisição da moradia via financiamento - caso do MCMV - não representa uma solução habitacional de fato, já que a alienação fiduciária permite, aos agentes financeiros, recuperar os imóveis de famílias endividadas. Esse aspecto é especialmente relevante ao se considerar que a maioria dos financiamentos ocorreu nos anos de 2013 e 2014, no pico de preço dos imóveis, e que a crise econômica na segunda metade da década pode ter comprometido a capacidade de pagamento das famílias. Em Curitiba, verificou-se o aumento real do preço médio ${ }^{14}$ das diferentes tipologias de apartamentos - de 1 a 4 quartos - em quase todos os bairros da cidade entre 2010 e 2014 . No caso dos imóveis com 2 ou 3 dormitórios, também foi observada a expansão da oferta para praticamente todas as regiões da cidade no mesmo intervalo. Já, no período seguinte, entre os anos de 2015 e 2018, houve retração da oferta e os preços reduziram, exceto para alguns bairros e produtos específicos (Martins, 2020).

Como já citado, no período de crise foi possível observar uma mudança na atuação das empresas e no perfil dos produtos imobiliários concluídos. Além do crescimento na oferta dos empreendimentos Compactos, cujos apartamentos são comercializados por valores "acessíveis" em função de suas dimensões reduzidas, destaca-se o direcionamento da produção para as faixas de renda mais alta, em imóveis de alto e altíssimo padrão. Além das alterações nos produtos, no intervalo recessivo (2015-2018) foram observados, em Curitiba, outros dois movimentos: a desvalorização de grande parte dos imóveis em face da inflação (mantendo-se, no entanto, a valorização considerando o período completo 20102018) e a redução da atuação das empresas financeirizadas (ibid.).

Praticamente todas as construtoras com capital aberto que investiram em Curitiba finalizaram seus produtos até o ano de 2015, o que indica que eles foram lançados no período de otimismo do setor. São exceções a MRV, com bom volume de produção entregue até 2018; a Cyrela, com poucas unidades finalizadas entre 2015 e 2017; e a Tecnisa e a Rossi, que tiveram seus últimos projetos concluídos em 2016. Com exceção da MRV, que produziu Habitação Social de Mercado, os produtos entregues após 2015 foram classificados como Multiuso 
(Tecnisa e Cyrela), Compacto (Rossi) ou Altíssimo Padrão (Rossi e Cyrela). No caso da MRV, é importante citar que houve uma elevação do valor-limite para enquadramento dos imóveis no programa MCMV na Região Metropolitana de Curitiba em 2015 (de $\mathrm{R} \$ 170$ para $\mathrm{R} \$ 200$ mil), ${ }^{15}$ o que facilitou a viabilização de projetos pelos incorporadores e se refletiu nos CVCOs emitidos nos anos posteriores (ibid.).

0 Gráfico 4, que indica as unidades habitacionais finalizadas em Curitiba, separadas por produto imobiliário e por ano, explicita os picos de produção dos produtos "inovadores". Em 2013 e 2014 os destaques são Habitação Social de Mercado e Condomínio-Clube. Nos anos seguintes, o total de unidades concluídas decresce, e os produtos que se destacam são, em 2015, ainda o Condomínio-Clube, mas com metade das unidades do ano anterior; e, em 2016, o Compacto, mas com um número menos expressivo de habitações. Em 2017 e 2018 retorna a HSM, mas com volume bem inferior ao da primeira metade da década. Também é possível notar, no gráfico, o quase "desaparecimento" do produto Condomínio-Clube - estrela da fase de expansão do mercado - após 2015, o crescimento do Compacto, a partir de 2014, e a produção concentrada do Multiuso entre os anos de 2014 e 2016, com projetos lançados no final da fase favorável ao setor. Já a conclusão das unidades nos produtos Tradicionais é bem mais estável ao longo do tempo, com menor variação no volume produzido e entre os produtos, mesmo nos diferentes momentos econômicos da década (ibid.). 0 destaque nessa categoria é o produto Médio Padrão. $O$ ano de 2016 é o único em que um produto "tradicional" teve mais unidades concluídas do que um da categoria "inovação", refletindo os ajustes do período de crise.
A pesquisa realizada em periódicos para identificar agentes e produtos imobiliários revelou também movimentos mais recentes do mercado, que não foram visualizados pela conclusão dos empreendimentos, mas que apareceram em notícias sobre as construtoras e os lançamentos imobiliários dos anos de 2018 e 2019. Essas informações indicaram algumas estratégias do mercado nos anos finais da década estudada.

Em 2018, a incorporadora Cyrela criou a marca Vivaz Residencial para atuar no segmento econômico, seguindo a tendência das "rivais" RNI e Eztec, também com capital aberto na Bovespa. A justificativa da empresa cita a forte demanda do mercado de baixa renda e a possibilidade de financiamento com recursos do FGTS a juros baixos. Segundo dados da Associação Brasileira de Incorporadoras Imobiliárias (Abrainc), de julho de 2017 a julho de 2018, os imóveis do programa MCMV responderam por $72 \%$ dos lançamentos e $65 \%$ das vendas no País, ${ }^{16}$ dado que reforça a importância dessa política habitacional para o setor imobiliário. Esse movimento se enquadra no que Aalbers (2017) define como a criação de condições e políticas urbanas, pelo Estado, para facilitar a financeirização da habitação.

Ainda com relação às expectativas do mercado, em entrevista no início de 2019,17 o presidente da MRV falou sobre as novas frentes de atuação da empresa. Uma delas é o lançamento de unidades maiores, voltadas para a classe média, expandindo a clientela e retomando um padrão que era executado antes do MCMV; a outra é a produção de imóveis para locação, bem localizados e com oferta de serviços, visando atrair a geração millennial. Também com foco no público jovem, os apartamentos compactos seguem em 
Gráfico 4 - Distribuição anual das UH em produtos imobiliários -

Curitiba, 2010-2018

Produtos Inovadores

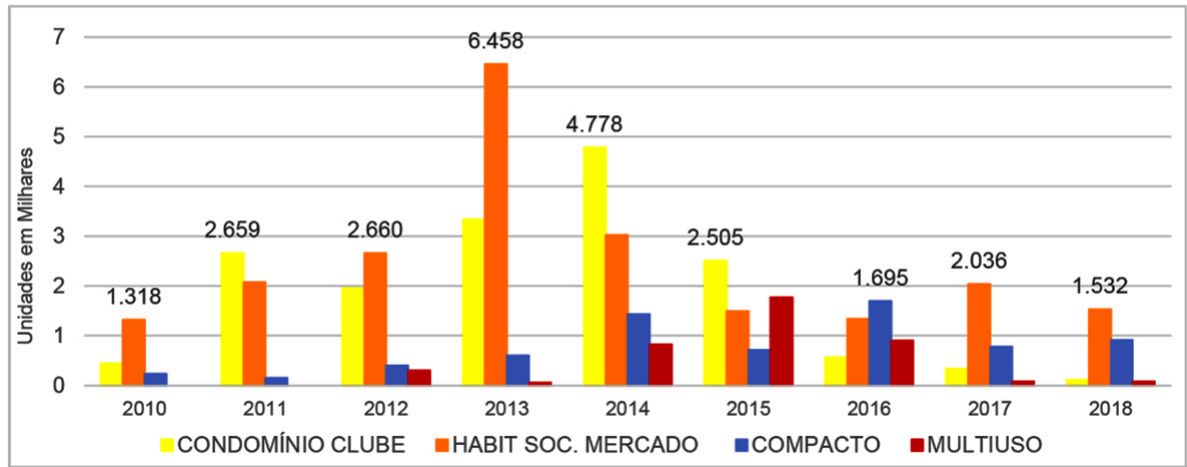

\section{Produtos Tradicionais}

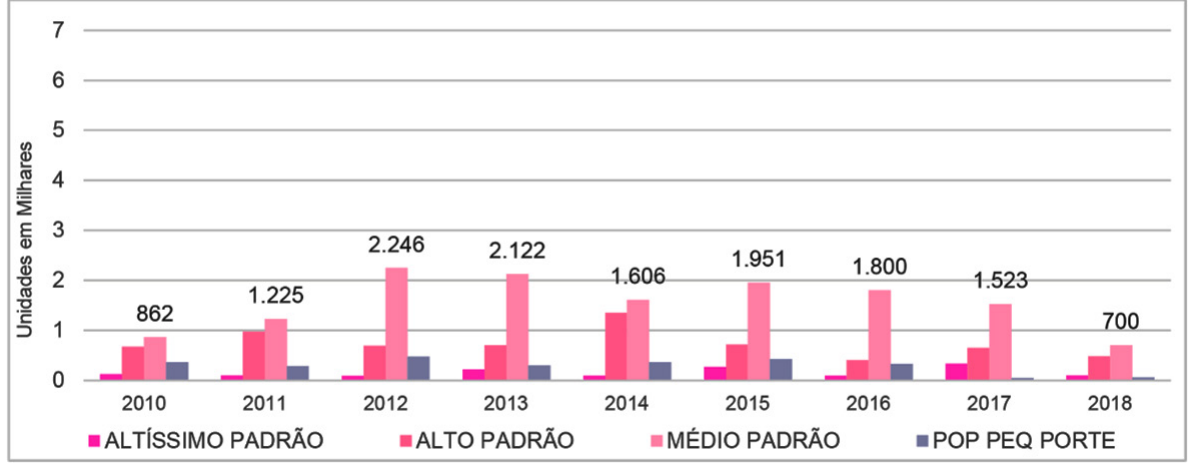

Fonte: Martins (2020); formatado pelas autoras em 2021.

alta. Um exemplo é o empreendimento All you need, concluído na região central de Curitiba em dezembro de 2019, com 321 unidades de 17 a $44 \mathrm{~m}^{2}$, parte delas já mobiliadas e decoradas e que oferece serviços como internet, loja de conveniência, aluguel de bicicletas e coworking. 0 regimento do condomínio prevê o aluguel de curta temporada, popularizado pelo aplicativo Airbnb. A Thá e a GT Building, responsáveis pelo projeto, esperam que $70 \%$ das unidades sejam locadas, com a compra realizada por investidores ${ }^{18}$ (Martins, 2020).

Em outra vertente, a pesquisa observou, nos lançamentos do final da década em Curitiba, um crescimento na oferta de imóveis de alto padrão, que possuem demanda solvável e buscam se destacar através da adoção de soluções sustentáveis, inovações tecnológicas 
e arquitetura autoral, características valorizadas no padrão de consumo contemporâneo. Até mesmo a palavra "apartamento" é substituída pelos termos "casas suspensas" ou "residências panorâmicas" nas propagandas. $\mathrm{Na}$ descrição dos empreendimentos, a utilização de adjetivos como único, incomparável, ímpar, singular, exclusivo, inconfundível, entre outros, ressalta a busca por diferenciação e exclusividade como definidora da produção imobiliária atual.

\section{Reflexões sobre a produção capitalista do espaço}

Investigar a produção habitacional realizada pelo mercado em Curitiba permitiu uma meIhor compreensão do processo de financeirização da habitação, que, na cidade, ocorreu via atuação de agentes capitalizados e/ou através de políticas públicas de financiamento habitacional. Para Aalbers (2017), apesar do neoliberalismo estar vinculado à ideia de "menos Estado e mais mercado", o Estado está presente no processo de financeirização, criando condições ou políticas para sua viabilização. Pírez (2018), ao avaliar a urbanização latino-americana, observa na ação estatal a busca por garantir tanto a reprodução do capital global como a acumulação dos capitais privados, sendo difícil encontrar uma intenção de fato pública. Nas palavras de Shimbo (2016, pp. 120-121), "a articulação contemporânea entre Estado, finanças e produção [...] possibilitou a formação de um complexo imobiliário-financeiro que [...] influenciou a estruturação das cidades brasileiras".
Nesse contexto, a pesquisa confirmou o crescimento da atividade privada na produção de habitação em Curitiba, com destaque para a execução do programa Minha Casa Minha Vida e para a produção das empresas de capital aberto, especialmente durante o momento econômico favorável no início da década. Ainda que se considere o mercado como principal agente produtor do espaço, diante dos já citados processos de concentração e de centralização do capital no setor imobiliário, é visível a participação do Estado na produção habitacional realizada na cidade, seja através da criação e instrumentalização do SFI; da concessão de crédito imobiliário via programa MCMV ou, localmente, do ajuste de parâmetros da legislação municipal e apoio da Cohab-CT, no caso dos projetos de Habitação Social de Mercado implantados nos bairros Santa Cândida e Cachoeira.

A forte demanda do segmento econômico pode ser explicada pelo déficit habitacional no Brasil. Mas, mesmo com execução do programa MCMV, a tendência verificada no período 2016 a 2019 foi de aumento no indicador, atualmente ao redor de 5,8 milhões de moradias (FJP, 2021). 0 crescimento do déficit deu-se especialmente nos componentes "domicílios improvisados" e "gasto excessivo com aluguel", em um possível reflexo da crise econômica aliada à valorização dos imóveis. Essa constatação reforça a leitura de Bolaffi (1979) sobre a questão habitacional no País. Para o autor, a construção de unidades habitacionais visa combater um falso problema, enquanto o desafio real está ligado à questão fundiária e à especulação do solo urbano. A política de produção de habitação, iniciada com o BNH, transfere recursos públicos para o setor privado e intensifica desigualdades. 
A estratégia de atuação do mercado, identificada na formatação dos produtos imobiliários, determina o espaço produzido e quem dele se apropria. 0 zoneamento e os parâmetros urbanísticos, ao mesmo tempo que viabilizam a ação do mercado, criam condicionantes ao uso dos edifícios e limitam sua forma e escala. Esses instrumentos, no entanto, não mudam a lógica de valorização do capital imobiliário, que se baseia em fatores como localização/distinção e inovação/padronização (Martins, 2020). Cabe aqui fazer referência à "reestruturação socioespacial" em curso nas metrópoles latino-americanas, segundo a qual a promoção imobiliária direciona o crescimento urbano e reduz a cidade a um negócio, intensificando processos espoliativos (Pereira, 2011, p. 23).

A lógica financeira incorporada na produção de moradia busca valorização e expansão territorial de forma contínua, o que reforçou a segregação socioespacial e a fragmentação do espaço urbano em Curitiba (Martins, 2020). A segregação decorre da estratégia de localização da produção imobiliária pautada na renda dos compradores, o que tende a hierarquizar e homogeneizar o espaço e os moradores de determinadas regiões. Nesse processo, ocorre a extensão artificial de áreas valorizadas, pela exportação de suas características imateriais para a vizinhança. A segmentação social é explicitada nas características e na divulgação dos produtos, nas quais elementos de diferenciação se destacam, delimitando seu público-alvo. Valores simbólicos são incorporados às estratégias de marketing, "promovendo estilos de vida" (Montes Ruiz e Durán Segura, 2018, p. 33), o que permite atingir novos patamares de preço.
A fragmentação do espaço foi intensificada devido à incorporação de novas áreas pelo mercado e à adoção da tipologia condominial de forma hegemônica, em produtos para diferentes públicos. A implantação de condomínios verticais de grande porte e com estratégias ostensivas de segurança, tanto em regiões nobres como em bairros periféricos de Curitiba, resulta em ruas sem vida e aumenta a insegurança no espaço público e a dependência do automóvel. Especialmente nos grandes empreendimentos, foram observadas soluções muito similares, seja em diferentes bairros ou até mesmo em outras cidades do País (Martins, 2020). Conforme observado por Volochko (2011), a reconfiguração dos espaços, em especial os periféricos, através dos novos produtos habitacionais, permitiu a superação da crise de reprodução do capital e trouxe outras crises, como a social, já que os novos projetos negam a forma urbana pela segregação e isolamento que instauram no espaço. Expandindo essa leitura para o cotidiano, pode-se intuir que a vida nos novos condomínios habitacionais limita as possibilidades de apropriação do espaço pelos moradores, ao mesmo tempo que impõe novas regras para o morar. Na leitura de Montes Ruiz e Durán Segura (2018), as imagens publicitárias produzidas pelo mercado imobiliário não são apenas representações do espaço, mas referências simbólicas que condicionam os desejos e as práticas espaciais.

Conclui-se, assim, que a produção habitacional recente, derivada da lógica financeira, resulta em um processo perverso, que não apenas modifica a prática socioespacial cotidiana, mas também torna mais frágil a coesão social nas cidades brasileiras, que já enfrentam 
desigualdades históricas na sua ocupação. imobiliária apenas no município de Curitiba, Assumindo as palavras de Tone (2010, p. 77), entende-se que a dinâmica estudada se rela"a generalização da produção de grandes con- ciona à metrópole, e seus efeitos ultrapassam domínios verticalizados abrangendo desde os as fronteiras municipais. No que tange aos terrenos mais 'periféricos' [...] até [...] áreas produtos habitacionais para o segmento ecomais valorizadas [...] expressa o grau de de- nômico, as características dos projetos e as imgradação social que vivemos". O aumento da plicações espaciais resultantes - segregação, produção habitacional "acessível à população fragmentação e homogeneização - possivelde 'variadas faixas de renda'”, ao invés de "de- mente se estendem aos municípios vizinhos à mocratizante [...]", caminha no sentido con- Curitiba. Ainda, a expansão da produção habitrário ao conceito de cidade, dado seu caráter tacional para áreas periféricas impacta outras antissocial (ibid., p. 30).

Por fim, cabe ressaltar que, apesar formas, não mercantis, de apropriação desses espaços, penalizando, sobretudo, a população de a pesquisa realizada tratar da produção excluída da economia formal.

\section{[I] https:// orcid.org/0000-0002-6037-3445}

Pesquisadora autônoma.

fabimoro75@gmail.com

\section{[II] https:// orcid.org/0000-0003-0426-8314}

Universidade Federal do Paraná, Setor de Tecnologia, Programa de Pós-Graduação em Planejamento Urbano, Laboratório de Habitação e Urbanismo. Curitiba, PR/Brasil.

gislenepereira42@gmail.com 


\section{Notas}

(1) Ver Fernandes e Firkowski (2014); Pilotto (2010) e Polucha (2010), referenciados em Martins (2020).

(2) A faixa 1 do programa MCMV, apesar de executada por construtoras privadas, não foi considerada produção de mercado, já que é o setor público que define os beneficiários das unidades, que recebem subsídios de até $90 \%$, muito superiores aos das demais faixas do programa. Dessa forma, os empreendimentos destinados à faixa 1 foram excluídos do universo da pesquisa.

(3) Inicialmente, foram identificados os empreendimentos enquadrados nos usos "habitação coletiva" e "conjunto habitacional de edifícios de apartamento", conforme a legislação urbanística vigente (lei n. 9.800/2000 e decreto municipal n. 183/2000). Destes, foram selecionados para a pesquisa todos os que possuíam alvará de vistoria final e, no mínimo, 4 pavimentos.

(4) O "padrão normal" está contido nos limites mínimos e máximos do diagrama de caixa (box plot), que permite avaliar dispersão, assimetria, caudas e dados discrepantes (outliers) de um conjunto de dados. Os limites do diagrama desconsideram os dados atípicos da curva de distribuição normal. Esse recurso da estatística descritiva permite visualizar as características do conjunto, no caso, o porte dos empreendimentos.

(5) Com a crise do setor, a família recomprou sua participação na Thá em 2016, mas a empresa está em recuperação judicial por conta de dívidas assumidas na época de seu controle pelo fundo.

(6) A Brookfield fechou capital em 2014 e atualmente se chama Tegra. A Camargo Correa Desenvolvimento Imobiliário (CCDI) fechou capital em 2012. A Abyara foi adquirida pela Agra, formando a Agre, depois incorporada pela PDG. No entanto, quando lançaram seus produtos em Curitiba, todas essas empresas tinham capital aberto.

(7) A "fração adquirida" corresponde à soma da área privativa da unidade habitacional com as áreas comuns e de garagem (se computáveis). Seu cálculo foi realizado por Martins (2020), a partir das informações de área construída e total de unidades dos CVCOs.

(8) Shimbo (2016) define a Habitação Social de Mercado como uma "zona intermediária híbrida", com fronteiras borradas de distinção, entre a produção da habitação de interesse social (promovida pelo Estado) e a produção de mercado para o segmento econômico.

(9) A relação de empreendimentos do programa MCMV em Curitiba foi obtida através da Secretaria Nacional de Habitação do Ministério do Desenvolvimento Regional (SNH/MDR). Alguns empreendimentos, como os da construtora Tenda, apesar de não listados oficialmente, ofereciam financiamento pelo programa em suas propagandas, como foi observado na busca em periódicos.

(10) Conforme Abramo (2007), a estrutura residencial segmentada promovida pelo mercado imobiliário é um mecanismo de "distinção espacial hierarquizada", pois reforça no espaço as divisões de classe e a estratificação socioeconômica da sociedade, garantindo homogeneidade socioespacial residencial. 
(11) A vulnerabilidade social de Curitiba foi identificada através do IVS - Índice de Vulnerabilidade Social -, elaborado pelo Ipea em 2015, a partir de dados do Censo Demográfico de 2010 e da Pnad Contínua. O índice é composto por 16 indicadores divididos em três dimensões: (1) Infraestrutura Urbana, (2) Capital Humano e (3) Renda e Trabalho. Seus resultados dividem porções do território com características socioeconômicas homogêneas em Unidades de Desenvolvimento Humano (UDHs). A sobreposição da produção imobiliária ao IVS está ilustrada em Martins (2020).

(12) A Linha Verde é um eixo de conexão urbana e metropolitana, implantado na antiga BR-116 após a mudança de função da rodovia, com a conclusão do Contorno Leste. Em 2011 foi criada uma Operação Urbana Consorciada, através da lei n. 13.909/2011, para incentivar a mudança de usos e o adensamento na área de influência do novo eixo de transporte.

(13) O Setor Estrutural é composto pelos principais eixos da estrutura urbana de Curitiba, definida no Plano Diretor de 1966 e baseada no tripé Uso do Solo, Transporte Coletivo e Sistema Viário. Ao longo desse setor é permitida maior densidade e verticalização.

(14) A análise da dinâmica de oferta e preços dos apartamentos, conforme número de quartos e localização, está detalhada em Martins (2020) e foi realizada a partir das pesquisas do Inpespar.

(15) Informação disponível em: Oferta de apartamentos econômicos volta a crescer em Curitiba. Gazeta do Povo, 12/02/2016. Disponível em: https://www.gazetadopovo.com.br/imoveis/ofertade-apartamentos-economicos-volta-a-crescer-em-curitiba-1pk75gx8qfwqbpowomrvuxao3/. Acesso em: 23 out 2019.

(16) Cyrela cria nova marca para voltar ao MCMV após 6 anos. Estado de São Paulo, 28/09/2018. Disponível em: https://economia.estadao.com.br/noticias/negocios,cyrela-cria-nova-marcapara-voltar-ao-minha-casa-minha-vida-apos-6-anos,70002522744. Acesso em: 14 jan 2020.

(17) 'Em um Brasil equilibrado, o mercado imobiliário pode dobrar', diz presidente da MRV. 1/3/2019. Entrevista para o portal Seu Dinheiro. Disponível em: https://www.seudinheiro.com/2019/mrv/ mrv-quer-ter-ate-25-do-vgv-focado-na-classe-media/. Acesso em: 19 nov 2019.

(18) Novo empreendimento da Thá preservará casarão no Centro e terá apês preparados para o Airbnb. Haus, Gazeta do Povo, 12/11/2017. Disponível em: https://www.gazetadopovo.com. br/haus/imoveis/novo-empreendimento-da-tha-e-focado-no-publico-da-era-digital-e-docompartilhamento/. Acesso em: 21 out 2019. 


\section{Referências}

AALBERS, M. B. (2017). The Variegated Financialization of Housing. International Journal of Urban and Regional Research, n. 41, pp. 542-554.

ABRAMO, P. (2007). A cidade COM-FUSA: a mão inoxidável do mercado e a produção da estrutura urbana nas grandes metrópoles latino-americanas. Revista Brasileira de Estudos Urbanos e Regionais. Rio de Janeiro, v. 9, n. 2, pp. 25-54.

ALAS, P. (2013). O fenômeno dos supercondomínios: verticalização na metrópole paulistana no início do século XXI. Dissertação de mestrado. São Paulo, Universidade de São Paulo.

BALISKI, P. (2019). Produção do espaço e periferização na metrópole: uma análise a partir do mercado formal de moradia popular em Fazenda Rio Grande/PR. Tese de doutorado. Curitiba, Universidade Federal do Paraná.

BOLAFFI, G. (1979). “Habitação e urbanismo: o problema e o falso problema”. In: MARICATO, E. (org.) A produção capitalista da casa (e da cidade) no Brasil industrial. São Paulo, Alfa-Ômega.

FIRKOWSKI, O. L. C. F.; MOURA, R. (orgs.) (2014). Curitiba: transformações na ordem urbana. Rio de Janeiro, Letra Capital/Observatório das Metrópoles.

FJP - Fundação João Pinheiro (2021). Déficit habitacional no Brasil - 2016-2019. Belo Horizonte, FJP.

HARVEY, D. (2005). A produção capitalista do espaço. São Paulo, Annablume.

HOYLER, T. (2016). Produção habitacional via mercado: quem produz, como e onde? Novos Estudos Cebrap. São Paulo, v. 35, n. 1, pp. 139-157.

LENCIONI, S. (2014). Reestruturação imobiliária: uma análise dos processos de concentração e centralização do capital no setor imobiliário. Eure, v. 40, n. 120, pp. 29-47.

MARTINS, F. M. (2020). Agentes, produtos e implicações da produção imobiliária de habitaão multifamiliar em Curitiba, 2010-2018. Dissertação de mestrado. Curitiba, Universidade Federal do Paraná.

MIOTO, B.; CASTRO, C. M. P.; SíGOLO, L. M. (2019). Expansão e desaceleração do mercado privado formal de moradia a partir dos anos 2000 na Região Metropolitana de São Paulo. Cadernos Metrópole. São Paulo, v. 21, n. 44, pp. 253-280.

MONTES RUIZ, A. P.; DURÁN SEGURA, L. A. (2018). Imágenes publicitarias y mercados inmobiliarios: propuesta para el estúdio del urbanismo neoliberal. URBS: Revista de Estudios Urbanos y Ciencias Sociales. Almería, v. 8, n. 2, pp. 27-38.

PEREIRA, P. C. X. (2011). “Agentes imobiliários e reestruturação: interesses e conflitos na construção da cidade contemporânea". In: PEREIRA, P. C. X. (org.). Negócios imobiliários e transformações sócio-territoriais em cidades da América Latina. São Paulo, FAU-USP.

PÍREZ, P. T. (2018). Analisar a urbanização latino-americana a partir da heterogeneidade dos modos de produção e consumo. Risco Revista de Pesquisa em Arquitetura e Urbanismo. On-line, v. 16, n. 3, pp. 45-62.

ROLNIK, R. (2015). Guerras dos lugares: a colonização da terra na era das finanças. São Paulo, Boitempo.

ROYER, L. de O. (2016). O FGTS e o mercado de títulos de base imobiliária: relações e tendências. Cadernos Metrópole. São Paulo, v. 18, n. 35, pp. 33-52. 
RUFINO, M. B. C. (2012). Incorporação da metrópole: centralização do capital no imobiliário e nova produção de espaço em Fortaleza. Tese de doutorado. São Paulo, Universidade de São Paulo.

SHIMBO, L. Z. (2016). Sobre os capitais que produzem habitação no Brasil. Novos Estudos Cebrap. São Paulo, v. 35, n. 2, pp. 119-133.

SíGOLO, L. M. (2014). O boom imobiliário na metrópole paulistana: o avanço do mercado formal sobre a periferia e a nova cartografia da segregação socioespacial. Tese de doutorado. São Paulo, Universidade de São Paulo.

TONE, B. B. (2010). Notas sobre a valorização imobiliária em São Paulo na era do capital fictício. Dissertação de mestrado. São Paulo, Universidade de São Paulo.

VOLOCHKO, D. (2011). Novos espaços e cotidiano desigual nas periferias da metrópole. Tese de doutorado. São Paulo, Universidade de São Paulo.

ZAP (2016). O auge e a queda do mercado imobiliário em uma década. Disponível em: http:// g1.globo.com/especial-publicitario/zap/imoveis/noticia/2016/04/o-auge-e-queda-do-mercadoimobiliario-em-uma-decada.html. Acesso em: 19 nov 2019

Texto recebido em 31/mar/2021

Texto aprovado em 1/jul/2021 